\title{
MODERN SCIENTIFIC WORLDVIEW AS A SEARCH FOR NEW WORLDVIEW IDEAS
}

\author{
(C) Anastasiya V. Perekrestova \\ Don State Technical University, Rostov-on-Don, Russian Federation \\ pereckrestova@mail.ru
}

In the course of development of surrounding reality by the person the results of this knowledge are always reflected and fixed in his consciousness where they take a form of skills, abilities, knowledge and also types of behaviour and communication. From the totality of these indicators, a certain model or a view of the world, is crystallized. Over the millennia of the mankind existence, many worldviews were created, and each of them had its own, unique vision of the surrounding reality and the specifics of its explanation. But only the scientific worldview is distinguished by the proper completeness of the idea of physical reality, because it includes the most important achievements of science, and thereby creates a certain understanding not only of the world itself, but also of the man`s place in it. This worldview is characterized by the ideas of general spheres, laws, levels and properties of reality, built into a holistic system. In its essence, the scientific worldview is a qualitative generalization of various scientific theories and their worldview synthesis, in other words, it represents a special form of knowledge systematization. Today, the worldview is a scientific ontology that not only studies the facets of existence, but also constantly stimulates the expansion of the cognition boundaries. In recent decades, due to the major changes in the information environment of society, the task of building an objective worldview has become especially important. In this sense, studies of the natural sciences, which precede ontological order ideas, and the integration of their results into the general model of reality, can contribute to the methodology of thinking for new interpretations of scientific discoveries and their adequate description.

Key words: scientific worldview, theoretical knowledge, rationality, information society, postnonclassical science, interdisciplinarity, worldview guidelines, thinking.

\section{[A.В. Перекрестова Современная научная картина мира как поиск новых мировоззренческих идей]}

В процессе освоения человеком окружающей действительности результаты этого познания всегда отражаются и закрепляются в его сознании, где приобретают вид навыков, умений, знаний, а также типов поведения и общения. Из совокупности именно этих показателей выкристаллизовывается определенная модель, или картина мира. За тысячелетия существования человечества было создано множество картин мира, и у каждой из них было свое, уникальное видение окружающей действительности и специфика ее объяснения. Но лишь научная картина мира отличается должной полнотой представления о физической реальности, ибо включает в себя наиболее важные достижения науки и тем создает определенное понимание не только самого мира, но и места человека в нем. Характеризуют эту картину представления об общих сферах, закономерностях, уровнях и свойствах действительности, выстроенные в целостную систему. По своей сути научная картина мира - качественное обобщение различных научных теорий и их мировоззренческий синтез, иными словами, она представляет собой особую форму систематизации знаний. Сегодня картина мира - это научная онтология, которая не только изучает грани бытия, но и постоянно стимулирует расширять границы познания. В последние десятилетия в связи с масштабными изменениями информационного окружения общества задача построения объективной картины мира приобретает особую важность. В этом смысле исследования естественных наук, предваряющих собой идеи онтологического порядка, и интеграция их результатов в общую модель реальности способны внести вклад в методологию мышления для новых трактовок научных открытий и их адекватного описания.

Ключевые слова: научная картина мира, теоретическое знание, рациональность, информационное общество, постнеклассическая наука, междисциплинарность, мировоззренческие ориентиры, мышление. 
Anastasiya V. Perekrestova - Ph.D. student, Don State Technical University, Rostov-on-Don, Russian Federation.

Перекрестова Анастасия Валерьевна - аспирант, Донской государственный технический универcumem, г. Ростов-на-Дону, Российская Федерация.

In the 21st century, science is the main form of human knowledge, which has recently had an increasingly significant impact on the real conditions of human life. Today, we have to comprehend the massive, sometimes unexpected and even dramatic impact of scientific and technological achievements on everyday life, which was unrepresentable a hundred years ago.

Knowledge of the world, in order to be considered objective, has always needed justification and systemic organization. The main task of science as a special type of cognitive activity is to provide these justification and systemic organization. But human existence is so diverse that science, even reflecting the world in its objectivity, gives only one of the sections of this existence. That is why it does not exhaust the whole culture, but only forms a separate facet of the majestic building of civilization, which correlates with other parts of the cultural massif. There are many types of theory and practice, always historically defined, but a distinctive feature of scientific knowledge is the ability to go beyond each of them and discover new subject worlds that can become objects of development only in the future stages of society development for mankind.

Global crises, the number of which is steadily growing in modern times, challenge the mankind to search for new worldview orientations. One of the consequences of this is the launch of the process of rethinking science. According to B.C. Stepin, "its dominant position in the system of cultural values was largely due to its technological projection. Today, it is important to combine the values of scientific and technological thinking with those social values that are represented by morality, art, religious and philosophical understanding of the world" [3, p. 458].

There is no doubt that the special status of science in modern culture was given by its growing role in public life; the interaction of science with human consciousness (with its various layers), obviously, takes on new features. The problems of constructing a scientific worldview, as well as its relationship with other forms of cognitive activity, from this perspective are especially acute. By its nature, this task is more philosophical, and at the same time it has great practical significance.

The latest philosophical dictionary gives such a definition of the concept of the scientific worldview: "a special form of theoretical knowledge that presents the subject of science research according to a certain stage of its historical development, through which specific knowledge, obtained in various fields of scientific search, is integrated and systematized" [3, p. 459].

As a holistic system of ideas about laws and most common properties of the surrounding reality, the scientific worldview exists as a complex structure, the components of which are the general scientific worldview and the worldviews of special sciences (biological, physical, geological, and other worldviews).

It should be emphasized here that the term "worldview" itself can be used in various meanings. For example, it designates the worldview structures underlying a certain historical era and its culture. In this case, it is synonymous with all terms that characterize the integrity of the worldview terms, such as "the model of the world," "the image of the world" or "the vision of the world." Thus, one of the leading Western researchers of various forms of knowledge systematization G. Holton presents the worldview in the form of a model of 
the world, which "summarizes the experience and innermost beliefs of a person and acts as a kind of mental map with which he checks his actions and is guided among things and events of real life" [7, p. 38]. The term "worldview" can also mean scientific ontology, that is a special type of theoretical knowledge that forms a scientific idea of the world. Then the concept of the scientific worldview denotes the horizon of systematization of knowledge that was obtained in a variety of scientific disciplines, while the scientific worldview acts as a holistic image of the world, an image that includes all ideas about both nature and society.

The term "scientific worldview" often refers to a certain system of ideas about nature obtained in all fields of natural science, similarly it is used to indicate the totality of that knowledge that was obtained in the social science and humanities. Finally, that vision of the subject matter of each particular science, which develops at the appropriate stage of its vast history and, by necessity, changes when one stage replaces another, is also formed through the concept of the scientific worldview.

As a result, as researchers state, the concept of "the scientific worldview" breaks down into interconnected concepts that denote a special type of this worldview, including "the socio-scientific worldview," "the natural science worldview," "the general science worldview," "the local science worldview." All of them are designations of special levels of systematization of scientific knowledge.

In the structure of the scientific worldview, two main levels are distinguished: conceptual and sensual-figurative. The first includes the main philosophical categories and principles that are specified in the scientific worldview both through the fundamental concepts of separate sciences and through the system of general scientific concepts; the second level includes images and visual representations.

Ideas about fundamental objects, about their typology, interaction and relationship, along with ideas about time and space, are the main components of the scientific worldview. Researchers emphasize systematizing, heuristic, and worldview functions among a number of those that the scientific worldview performs in the interdependent processes of accumulation and development of theoretical knowledge. Characteristic both for the general scientific worldview and for all special ones, these functions have a systemic organization. Thus, the scientific worldview can be represented as a developing formation.

The historical dynamics of the scientific worldview fits into a certain scheme, in any case, it is customary to single out 3 large-scale stages: the stage of pre-disciplinary science, the stage of disciplinary-organized science and the present stage, at which interdisciplinary interactions are strengthened. According to V.S. Stepin, at the present stage, the scientific worldview "incorporating a set of fundamental scientific results and synthesizing them within the framework of a holistic image of the development of the Universe, wildlife, man and society $<\ldots>$ actively interacts with the worldview universals of culture, in the context of which its development takes place. On the one hand, it adapts to them, but on the other hand, it introduces cardinal mutations into established cultural mentalities" [5, pp. 354-355].

At the first stage, the functioning of the scientific worldview was closely connected with the emergence of the mechanistic worldview of the New Age era and transformed its entire culture. The latter in its internal unity at that time acted not only as a special scientific worldview, but also as a natural science and general science. This unity was provided by endowed with the status of comprehensive principles of mechanics, it was set through their system, since they were broadcast to all neighbouring branches of knowledge.

The formation of a special system of science falls on the present, newest stage in the development of the scientific worldview. At this stage, the processes of disciplinary synthesis of knowledge are intensified, which is carried out on the basis of the widely accepted principles of global evolutionism. As V.S. Stepin and L.F. Kuznetsova note, the feature 
of the modern scientific worldview is the fact that it "is not formed on the basis of unification of all fields of knowledge and their reduction to the ontological principles of an individual science, but on the unity in the variety of various disciplinary ontologies" [6, p. 254].

The paradigm of the scientific worldview is determined by the obvious fact that it sets out a system of principles and attitudes that are used in the process of mastering the universe. Moreover, the scientific worldview is able to effectively direct the very movement of scientific thought, by imposing certain restrictions on the nature of the assumptions of "legal," or "reasonable" hypotheses. There is no doubt that the content of the scientific worldview, since it has a powerful influence on the formation of ethical, socio-cultural, as well as logical and methodological norms of scientific research, determines the way of vision of the world. Therefore, it is legitimate to speak about its functions, such as normative and psychological. Thus, the scientific worldview not only creates a well-known general theoretical background of research, but also effectively coordinates the guidelines of scientific search.

As already mentioned, a person's specific ideas about the world represent each era. The situation of the beginning of the 21st century is not an exception, for now there is an active adoption of the standards of that new stage of the development of science, which is entirely guided by the principle of methodological pluralism, and the resulting rapid transformation to which the scientific worldview is undergoing. Of course, this is also facilitated by the ideas of globalization, self-development and informatization of society relevant to the entire mass of modern culture. To formalize the novelty of the existing scientific worldview as in the full sense "unique" novelty, the reality of recent decades provides not only special materials, but also specific conditions. That is why the transformation of the worldview in connection with the massive changes in the information environment of society, as well as its information culture, needs deep study. Such a study should take into account the most important features and logic of the evolution of this worldview.

It is indisputable that the modern scientific worldview has evolved over the past centuries, this was expressed in a movement from the classical worldview to the non-classical and further to the post-classical. The European science started at an era when the classical scientific worldview was adopted, the foundation of which was laid by the revolutionary achievements of such famous scientists as Galileo and Newton; it dominated, claiming to have true knowledge, and this has been its privilege for a long time, almost until the end of the 19th century.

The classical worldview quite corresponds to the graphic image of a linear development, progressively directed, as well as rigidly and unambiguously determined: the present here is determined by the past as initially as it itself determines the future. Thus, just as, according to Schopenhauer's treatise "On the Freedom of the Will," in strict accordance with the action of already known motives on the innate and unchanging individual character of a person, all his individual actions can be accurately predicted, absolutely all the states of the world can be predicted and calculated in the classical scientific worldview.

The description of objects in the classical scientific worldview was carried out by assuming that they exist on their own in a rigidly defined coordinate system. A cause-andeffect dependence was erected as an explanatory sample, strictly unambiguous and strengthening the bold claims of scientific rationality to the "discovery" of such a general rule or method that would be only true, and therefore could guarantee the construction of the true theory.

At the turn of the 19th-20th centuries the classic scientific worldview was replaced by a nonclassical one, the first theories of thermodynamics, "went beyond" the laws of classical mechanics and challenged their universality, led to this worldview. Gradually, there was a belief that random processes in thermodynamics do not turn out to be something side 
and external, on the contrary they are just inherent in the system, unlike classical mechanics, where they did not affect this system.

The determination scheme arising in the non-classical scientific worldview is more flexible than in a simple linear process, in addition, such a new factor as the role of the case is taken into account. As for the development of the system, it is thought of in a directional way, and the very state of the latter at every moment of time is not determined; all changes are presumably subject to the law of probability and large numbers. Deviation is nevertheless more likely than it is larger, since each time there is an approximation of a real phenomenon to the general line, that is, to "the law of the average."

Strict determinacy at the level of the system as a whole is combined with its complete absence at the level of individuals. This new form of determination quickly received a "registration" in theory and gained the name "statistical pattern" there.

In creating the image of the post-nonclassical scientific worldview, that is a tree branching graphics, the merit of I. Prigozhin's school is great, it was developed taking into account its brilliant achievements. Here, the future is always uncertain, both from the very beginning and at any given moment in time, and as far as development is concerned, it can take one of several paths, which is almost always determined by the influence of some minor factor.

Meanwhile, there is a reason to believe that the scientific worldview in the postnonclassical era includes categories and reflexion methods that allow combining data from a variety of disciplines with a powerful categorical apparatus of philosophy, linking them into the system. It seems that "theoretical strength" of this sought system will guarantee, at least, the actualization of a number of new opportunities for the effective formation of a generally accepted and holistic scientific worldview in modern culture. In fact, the study of the very problem of the worldview, the most complex and multidimensional problem, is equivalent to the search for an effective worldview of the future. The emerging question is exactly how the latest scientific approaches and achievements, modern resources and technologies will be realized.

At the moment, the analysis of all social structures in the post-nonclassical scientific worldview is invariably carried out through the study of open non-linear systems. In these systems, the role of initial settings and conditions, as well as individuals included in them, numerous random factors and local changes is very significant. This new imperative of post-nonclassics significantly influenced its methodology, in which such concepts as bifurcation, strange attractors, fluctuation, nonlinearity, dissipation are very popular.

In modern times, there is a particularly relevant situation when the scientific worldview begins to interact with other variants of knowledge and understanding of reality, that leads to the need for greater worldview tolerance, and fits into the idea of open rationality, the legitimacy of which is ensured by recognizing the fact that the process of searching for truth itself is infinite. According to the famous researcher V.S. Shvyrev, open rationality implies "an attentive and respectful attitude to alternative worldviews that arise in other cultural and worldview traditions than modern science, $<\ldots>$ mutual enrichment of various, but equal cognitive positions" [8, p. 98].

Summing up, it should be said that the modern scientific worldview, or rather, its development, can be considered as one of the most important aspects of searching for not only new worldview meanings, but also answers to the historical challenge facing civilization of the 21st century. It is the inclusion in the solution of the most pressing problem of choosing life strategies of mankind, as well as the problem of searching for new and optimal ways of civilizational development that determines its general cultural meaning. The scientific worldview clearly records changes that are taking place in modern science. Searching for new worldview ideas, developed not only in art, philosophy or religion, but also in all other areas of culture correlate with these changes. Since, at the present stage 
of development, the scientific worldview is connected with the ideals of open rationality and consistently embodies them, its most important worldview consequences are associated with philosophical and worldview values, as well as those ideas that grow on the basis of alternative cultural traditions that can lead a person to the new horizons in the future.

\section{Лumepamypa}

1. Кузнецов Б.Г. Эволюция картины мира. М.: АН СССР. 1961.

2. Микешина Л.А., Опенков М.Ю. Новые образы познания и реальности. М., 1997.

3. Новейший фрилософрский словарь / Сост. А.А. Грицанов. Минск, 1999.

4. Пригожин И., Стенгерс И. Порядок из хаоса. М., 1986.

5. Степин В.С. Теоретическое знание. М., 1999.

6. Степин В.С., Кузнецова Л.Ф. Научная картина мира в культуре техногенной цивилизации. М., 1994.

7. Холтон Дж. Что такое «антинаука» // Вопросы философиии. 1992. № 2. С. 26-58.

8. Швырев В.С. Рациональность как ценность культуры. М., 2003.

\section{References}

1. Kuznetsov B.G. Evoliutsiia kartiny mira [Evolution of the world view]. Moscow: USSR ACADEMY OF SCIENCES. 1961 (in Russian).

2. Mikeshina L.A., Openkov M.Yu. Novye obrazy poznaniia i realnosti [New images of knowledge and reality]. Moscow. 1997 (in Russian).

3. Noveishii filosofskii slovar [The latest philosophical dictionary]. Compiled by A.A. Gritsanov. Minsk. 1999 (in Russian).

4. Prigozhin I., Stengers I. Poriadok iz haosa [Order from chaos]. Moscow. 1986 (in Russian).

5. Stepin V.S. Teoreticheskoe znanie [Theoretical knowledge]. Moscow. 1999 (in Russian).

6. Stepin V.S., Kuznetsova L.F. Nauchnaia kartina mira v kulture tekhnogennoi tsivilizatsii [Scientific worldview in the culture of man-made civilization]. Moscow. 1994 (in Russian).

7. Holton J. Chto takoe "antinauka". Voprosy filosofii [What is "anti-science". Questions of philosophy]. 1992. No. 2. pp. 26-58 (in Russian).

8. Shvyrev V.S. Ratsionalnost kak tsennost kultury [Rationality as a value of culture]. Moscow. 2003 (in Russian). 